\title{
AN AMMONIA OPTICAL SENSOR SILCA MIROSPHERES DOPED WITH NICKEL(II) ION AND REFLECTANCE TRANSDUCTION
}

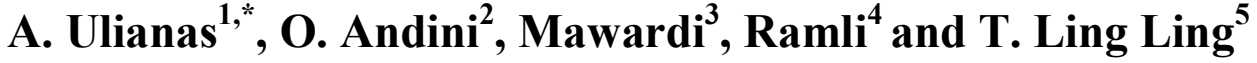 \\ 1,2,3 Department of Chemistry, Faculty of Mathematics and Science, Universitas Negeri Padang \\ 25131, Sumatera Barat, Indonesia \\ ${ }^{4}$ Department of Physic, Faculty of Mathematics and Science, Universitas Negeri Padang, 25131, \\ Sumatera Barat, Indonesia \\ ${ }^{5}$ Southeast Asia Disaster Prevention Research Initiative (SEADPRI-UKM), Institute for \\ Environment and Development (LESTARI), Universiti Kebangsaan Malaysia, 43600 UKM \\ Bangi, Selangor, Malaysia. \\ *E-mail: alizar_chem@yahoo.co.id
}

\begin{abstract}
An optical sensor based on silica micromaterial doped with $\mathrm{Ni}(\mathrm{II})$ ion has been developed for quantitation of ammonia $\left(\mathrm{NH}_{3}\right)$ concentration using reflectometric transduction in an aqueous environment. The as-synthesized silica nanospheres were immobilized with $\mathrm{Ni}$ (II) ion via electrostatic interaction between positively charged divalent transition metal ion and negatively charged terminal silanol groups at silica microspheres surface. The optical microsensor demonstrated a colour change from green to blue upon introduced with $\mathrm{NH}_{3}$ solution, as a result of the formation of blue-hued hexamminenickelate(II) $\left(\left[\mathrm{Ni}\left(\mathrm{NH}_{3}\right)_{6}\right]^{2+}\right)$ complex on the silica microspheres surface, and a maximum reflectance response was attained at the wavelength of $615 \mathrm{~nm}$. The response time of the silica microspheres-based sensor is rapid towards the reflectance determination of $\mathrm{NH}_{3}$, i.e. $<1$ min at optimum $\mathrm{pH} 6$. The linear response range of the developed reflectometric $\mathrm{NH}_{3}$ microsensor was acquired from $0.0003 \mathrm{M}$ to $0.008 \mathrm{M}$ $\left(\mathrm{R}^{2}=0.9826\right)$ with a limit of detection (LOD) of $0.0012 \mathrm{M}$. The ammonia optical sensor response is good reproducibility with a relative standard deviation (RSD) obtained at $0.25 \%(n=7)$. The recovery test exhibited satisfactory results of $101.5 \%$ when the fabricated sensor was applied for the determination of $\mathrm{NH}_{3}$ in a polluted water sample collected from landfill wastewater.
\end{abstract}

Keywords: Optical Sensor, Silica Microsphere, Reflectance, Transduction, Sensor Response

(C) RASĀYAN. All rights reserved

\section{INTRODUCTION}

Ammonia $\left(\mathrm{NH}_{3}\right)$ is an important substance consisting of hydrogen and nitrogen elements that contribute significantly to the nutritional needs of earthly lives via serving as a precursor to food and fertilizers. Besides, $\mathrm{NH}_{3}$ is a widely used source of nitrogen fertilizers, and as a building block in the production of pharmacy products, plastics, explosives, textiles, pesticides, dyes and a wide variety of chemicals. Also, much colorless ammonia is produced from agricultural practices, such as fertilizer application, animal feeding ${ }^{1}$. However, exposure to low levels of $\mathrm{NH}_{3}$ might affect human health especially people with asthma, whilst exposure to larger amounts of $\mathrm{NH}_{3}$ could result in changes in various organs, decreases in lung function and effects on nerve conditions ${ }^{2-4}$.

If the ammonia concentration is higher than $25 \mu \mathrm{g} / \mathrm{L}$ in water it can be toxic to aquatic life, Furthermore, the World Health Organization shows that the odor threshold of ammonia concentration at alkaline $\mathrm{pH}$ is around $1.5 \mathrm{mg} / \mathrm{L}$, while the taste threshold $35 \mathrm{mg} / \mathrm{L}^{7}$ and the norm for indoor air pollution of air for particulate matter is around $20 \mu \mathrm{g} / \mathrm{m}^{38}$. Besides, The European Association for drinking water has set a maximum limit of ammonia in water is $0.5 \mathrm{mg} / \mathrm{L}^{9}$. Thus, it is necessary to monitor $\mathrm{NH}_{3}$ concentrations in the environment, especially in the water body.

Rasayan J. Chem., 13(2), 860-867(2020)

http://dx.doi.org/10.31788/RJC.2020.1325424 
Some methods that have been reported to detect $\mathrm{NH}_{3}$ including colorimetry, fluorometry, electrochemical analysis and titrimetric measurement. Nevertheless, these methods possess several disadvantages, such as low sensitivity, poor selectivity, complicated operating procedure or toxic organic reagents used ${ }^{10}$. And, the immobilization matrices, which have been adopted in the previous reported $\mathrm{NH}_{3}$ optical sensor fabrications as the supporting substrates of receptors encompass fluorescent silver (Ag) nanoclusters ${ }^{10}$, chlorophenol red (CPR)-coated poly(methyl methacrylate) (PMMA) membrane ${ }^{1}$, cholesteric film of $\mathrm{Cu}$ (II)-doped cellulose nanocrystals ${ }^{11}$, amine-functionalized $\mathrm{ZnO}$ nanoflakes ${ }^{2}$.

In this study, an optical reflectance sensor was developed for $\mathrm{NH}_{3}$ detection in an aqueous environment. Silica microspheres immobilized with $\mathrm{Ni}(\mathrm{II})$ ion through ionic bonding was used to quantify $\mathrm{NH}_{3}$ concentration with optical reflectance transduction method. Upon reaction with $\mathrm{NH}_{3}$ in water surrounding, the green-hued $\mathrm{Ni}(\mathrm{II})$ ion-immobilized silica microspheres form blue-coloured hexamminenickelate(II) $\left(\left[\mathrm{Ni}\left(\mathrm{NH}_{3}\right)_{6}\right]^{2+}\right)$ complex (Eqn.-1). The color change of the dye-doped microsensor in relation to the concentration of $\mathrm{NH}_{3}$ in solution demonstrated high sensitivity, fast response time and facile assay of $\mathrm{NH}_{3}$ concentration.

$$
\begin{aligned}
& {\left[\mathrm{Ni}\left(\mathrm{H}_{2} \mathrm{O}\right)_{6}\right]^{2+}+6 \mathrm{NH}_{3} \rightleftharpoons\left[\mathrm{Ni}\left(\mathrm{NH}_{3}\right)_{6}\right]^{2+}+6 \mathrm{H}_{2} \mathrm{O}} \\
& \text { green } \\
& \text { blue }
\end{aligned}
$$

\section{Chemicals and Instruments}

\section{EXPERIMENTAL}

Ammonia $\left(\mathrm{NH}_{3}\right)$, nickel(II) chloride hexahydrate $\left(\mathrm{NiCl}_{2} \cdot 6 \mathrm{H}_{2} \mathrm{O}\right)$ and sodium dihydrogen phosphate $\left(\mathrm{NaH}_{2} \mathrm{PO}_{4}\right)$ were purchased from Merck. Tetraethyl orthosilicate (TEOS) and ethanol were supplied by Aldrich, whilst disodium hydrogen phosphate $\left(\mathrm{Na}_{2} \mathrm{HPO}_{4}\right)$ was procured from Fluka. The instruments used in this study were ultra sonicator, UV-DRS Spectrophotometer (SPECORD 210 PLUS), Fourier-transform infrared spectroscopy (FTIR GX infra-red spectrophotometer, Perkin Elmer), X-Ray Diffraction (XRD-PW3040/60) and scanning electron microscopy (SEM, LEO 1450VP).

\section{Preparation of Silica Microspheres}

Silica microspheres were synthesized following the method reported before with some modifications ${ }^{12} .2$ $\mathrm{mL}$ of deionized water was mixed with $5 \mathrm{~mL}$ of concentrated $\mathrm{NH}_{3}$ solution and $20 \mathrm{~mL}$ of ethanol. This mixture was sonicated at room temperature $\left(25^{\circ} \mathrm{C}\right)$ for $10 \mathrm{~min} .2 \mathrm{~mL}$ of TEOS and $4 \mathrm{~mL}$ of ethanol were then added, and the sonication process was continued for another $30 \mathrm{~min}$. The silica microparticles were isolated by centrifugation at $4000 \mathrm{rpm}$ for $20 \mathrm{~min}$ followed by sequentially washing with abundant ethanol and deionized water, and dried in an oven at a temperature of $75^{\circ} \mathrm{C}$.

\section{Optimization of $\mathrm{NH}_{3}$ Sensor Optical Reflectance Response}

Optimization of the silica microspheres-based $\mathrm{NH}_{3}$ sensor was first carried out by varying the $\mathrm{Ni}$ (II) ion loading at $0.0005 \mathrm{M}, 0.0010 \mathrm{M}, 0.0030 \mathrm{M}, 0.0050 \mathrm{M}, 0.0100 \mathrm{M}, 0.0300 \mathrm{M}$ and $0.0500 \mathrm{M}$, whilst the concentration of $\mathrm{NH}_{3}$ solution was fixed at $0.0100 \mathrm{M}$. The highest optical intensity of sensor response at maximum reflectance wavelength indicates optimum $\mathrm{Ni}(\mathrm{II})$ ion loading on the silica microspheres surface. The effect of $\mathrm{pH}$ on the $\mathrm{NH}_{3}$ sensor response was conducted by changing the $\mathrm{pH}$ of $0.0100 \mathrm{M}$ $\mathrm{NH}_{3}$ solution $\mathrm{pH}$ from $\mathrm{pH} 5$ to $\mathrm{pH} 8$ with sodium phosphate buffer. The highest reflectance intensity shows the optimum $\mathrm{pH}$ of the $\mathrm{NH}_{3}$ optical sensor. Response time and stability of the sensor are determined by exposing the $\mathrm{Ni}$ (II) ion-immobilized silica microspheres to a constant concentration of $\mathrm{NH}_{3}$ solution at $0.0100 \mathrm{M}$, and optical reflectance response at $615 \mathrm{~nm}$ was taken intermittently during an experimental period of $180 \mathrm{~min}$. The $\mathrm{NH}_{3}$ optical sensor response time is indicated by the maximum plateau reflectance signal, whilst the stability of the developed sensor is estimated at the point when reflectance intensity begins to decline ${ }^{13}$. Calibration curve of the sensor was established with various $\mathrm{NH}_{3}$ concentrations, i.e. $0.0003 \mathrm{M}, 0.0005 \mathrm{M}, 0.0008 \mathrm{M}, 0.0010 \mathrm{M}, 0.0030 \mathrm{M}, 0.0050 \mathrm{M}$ and $0.0080 \mathrm{M}$ under sensor optimal conditions. Limit of detection (LOD) is the smallest analyte concentration that can be measured by the optical $\mathrm{NH}_{3}$ sensor method.

\section{Reproducibility and Recovery Studies}

Reproducibility test of the transition metal-doped reflectance sensor involved batch production of seven units of $\mathrm{NH}_{3}$ sensors under the same conditions and fabrication technique and the reflectance response of 
RASĀYAN J. Chem.

Vol. 13 | No. 2 |860 - 867| April - June | 2020

each fabricated sensor with $0.0100 \mathrm{M} \mathrm{NH}_{3}$ was recorded at $615 \mathrm{~nm}$ for subsequent calculation of sensor's reproducibility relative standard deviation (\%RSD) percentage. The recovery performance of the $\mathrm{NH}_{3}$ optical sensor is determined by calculating the percent recovery of $\mathrm{NH}_{3}$ using Eqn.-2,

$$
\% \text { Recovery }=\mathrm{Cs} / \mathrm{C} \times 100 \%
$$

where $\mathrm{C}$ is the actual concentration of $\mathrm{NH}_{3}$ being spiked into the water sample and $\mathrm{Cs}$ is the concentration of $\mathrm{NH}_{3}$ determined by the developed reflectometric $\mathrm{NH}_{3}$ sensor ${ }^{13}$. The developed optical sensor has been used to detect $\mathrm{NH}_{3}$ content in wastewater collected within the landfill vicinity.

\section{Characterizations of Silica Microparticles}

\section{RESULTS AND DISCUSSION}

Figure-1 shows the FTIR and XRD spectra as well as SEM image of the as-synthesized silica microspheres. Stretching vibration of silanol functional groups, i.e. -OH from $\mathrm{Si}-\mathrm{OH}$ can be perceived at $3279 \mathrm{~cm}^{-1}$ with the corresponding bending vibration observed at $2106 \mathrm{~cm}^{-1}$ (Fig.-1a) Siloxane groups can be seen with the emergence of the absorption band at $1083 \mathrm{~cm}^{-1}$, indicating asymmetric stretching vibration of $\mathrm{Si}-\mathrm{O}$ group in $\mathrm{Si}-\mathrm{O}-\mathrm{Si}$, whilst the absorption peak at $797 \mathrm{~cm}^{-1}$ corresponds to the symmetric stretching vibration of $\mathrm{Si}-\mathrm{O}$ group in $\mathrm{Si}-\mathrm{O}^{-} \mathrm{Si}^{14}$. XRD spectrum in Fig.-1b reveals that the as-prepared silica microspheres formed non-crystalline solid with amorphous structure ${ }^{15}$. Scanning electron micrograph in Fig.-1c depicts the morphology of silica microparticles, whereby good spherical morphology and excellent homogeneous monodispersing ${ }^{16}$ was discernible with diameter in the micrometer range of $502 \mathrm{~nm}-614 \mathrm{~nm}$.

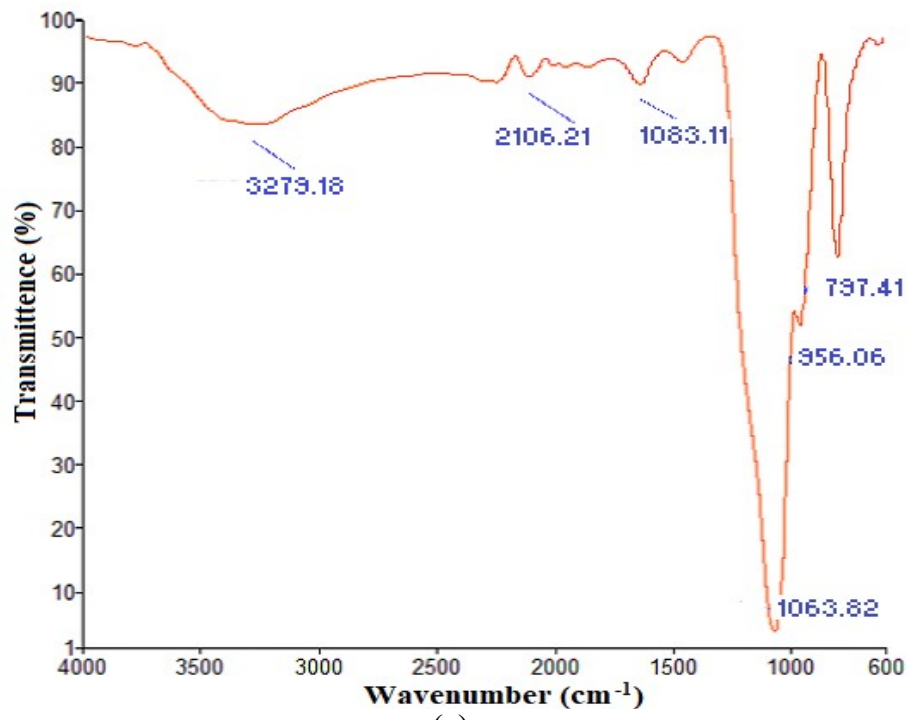

(a)

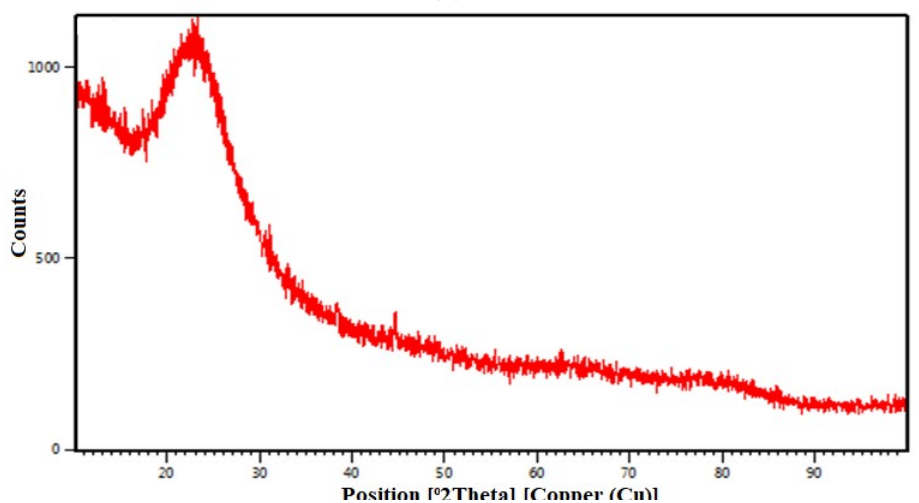

(b) 
RASĀYAN J. Chem.

Vol. 13 | No. 2 |860 - 867| April - June | 2020

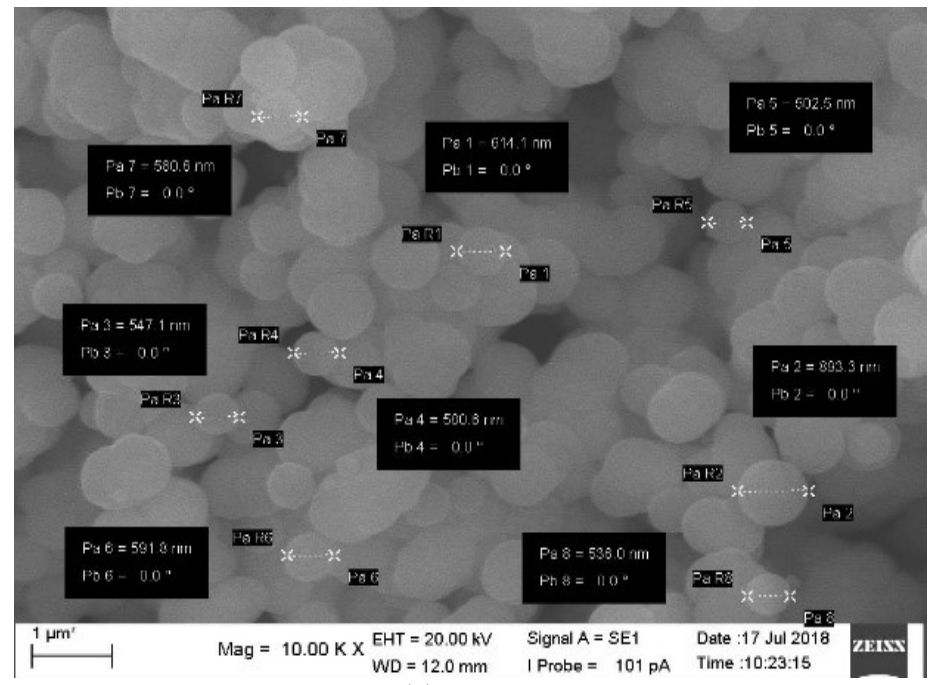

(c)

Fig.-1: (a) FTIR and (b) XRD Spectra, and (c) SEM Image of the prepared Silica Microspheres

\section{Optical $\mathrm{NH}_{3}$ Sensor Response}

The reflectance response of $\mathrm{NH}_{3}$ sensor based on silica microspheres doped with nickel(II) ion is exhibited in Fig.-2. The green-hued $\mathrm{Ni}$ (II) ion-modified silica microspheres showed a maximum reflectance response at $615 \mathrm{~nm}$. After reaction with $\mathrm{NH}_{3}$ via a dative covalent bond, whereby the nonbonding electrons of $\mathrm{NH}_{3}$ acted as Lewis base or electron donor, and the metal ion acted as a Lewis acid, the electron acceptor and that forming the charge-transfer complex, the hexamminenickelate(II) $\left(\left[\mathrm{Ni}\left(\mathrm{NH}_{3}\right)_{6}\right]^{2+}\right)$ immobilized on the silica microspheres surface, thereby resulted in a color change of the substrate from green to blue, and an enhancement in reflectance signal at $615 \mathrm{~nm}$ was observed. The addition of deionized water on the Ni(II)-doped silica microparticles was conducted as a controlled experiment and gave negligible optical reflectance response. Silica microparticles substrate alone demonstrated higher reflectance response compared to $\mathrm{Ni}$ (II) ion-immobilized silica microspheres, which was attributed to its white background color matrix that could reflect higher light intensity than dye-doped silica microspheres.

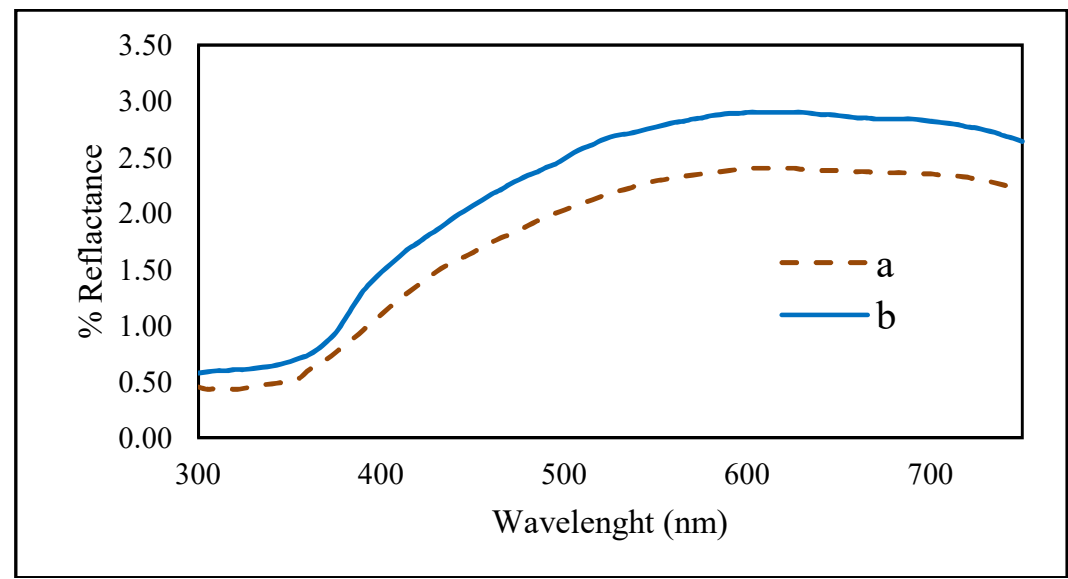

Fig.-2. Optical Reflectance Response of the Silica Microspheres-based Sensor in the Presence (a) and Absence (b) of $0.01 \mathrm{M} \mathrm{NH}_{3}$

Optimizing Optical $\mathrm{NH}_{3}$ Sensor Response in Terms of $\mathrm{Ni}$ (II) ion Loading and pH Effect

Figure-3a represents the effect of $\mathrm{Ni}$ (II) ion concentration on the microspheres sensor response towards reaction with $0.0100 \mathrm{M} \mathrm{NH}_{3}$ solution. The $\mathrm{NH}_{3}$ sensor response increased as increasing the $\mathrm{Ni}$ (II) ion 
RASĀYAN J. Chem.

Vol. 13 | No. 2 |860 - 867| April - June | 2020

loading on the silica microspheres and reached an optimum reflectance response at $0.0030 \mathrm{M} \mathrm{Ni}$ (II) ion when the optical signal at $615 \mathrm{~nm}$ started to reach a plateau state. At this stage, the available $\mathrm{NH}_{3}$ molecules have been entirely consumed to form immobilized $\left[\mathrm{Ni}\left(\mathrm{NH}_{3}\right)_{6}\right]^{2+}$ complex ${ }^{17}$. The optimum $\mathrm{Ni}$ (II) ion loading at $0.0030 \mathrm{M}$ was then employed in $\mathrm{pH}$ optimization of the $\mathrm{NH}_{3}$ sensor.

The effect of $\mathrm{pH}$ on the $\mathrm{NH}_{3}$ sensor response is illustrated in Fig.-3b. At $\mathrm{pH}$ below $\mathrm{pH} 6, \mathrm{NH}_{3}$ tends to convert to $\mathrm{NH}_{4}{ }^{+}$ion due to the availability of excessive $\mathrm{H}^{+}$ions in acidic conditions, and that the formation of $\left[\mathrm{Ni}\left(\mathrm{NH}_{3}\right)_{6}\right]^{2+}$ complex was not favorable. In a highly basic environment, on the other hand, hydroxide $\left(\mathrm{OH}^{-}\right)$ions are responsible for the alkalinity of a reaction medium. This resulted in the formation of nickel(II) hydroxide $\left[\mathrm{Ni}(\mathrm{OH})_{2}\right]$ precipitation in an alkaline environment. The charge effect to adsorption was reported before ${ }^{18}$. Therefore, lower reflectance response was obtained in both acidic and basic reaction media. Optimum $\mathrm{NH}_{3}$ sensor response was attained at $\mathrm{pH} 6$ ascribed to the formation of $\left[\mathrm{Ni}\left(\mathrm{NH}_{3}\right)_{6}\right]^{2+}$ complex was more favorable at this $\mathrm{pH}$. The same $\mathrm{pH}$ was also reported before as the optimum $\mathrm{pH}$ for the $\left[\mathrm{Ni}\left(\mathrm{NH}_{3}\right)_{6}\right]^{2+}$ charge-transfer complex to form optimally ${ }^{19}$.

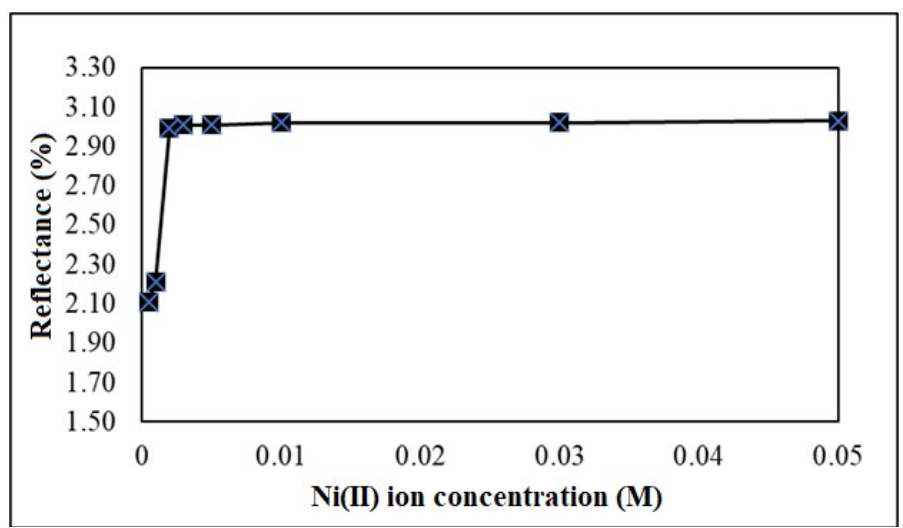

(a)

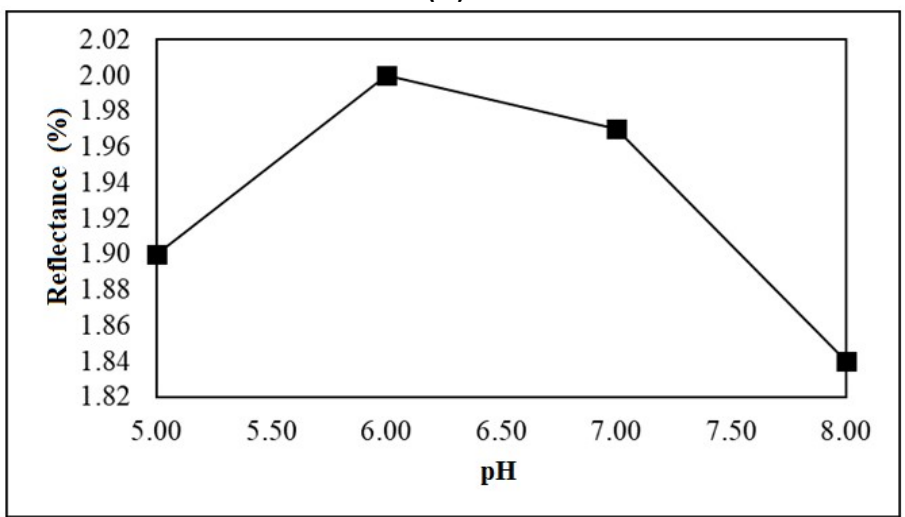

(b)

Fig.-3: The Effect of (a) Ni(II) Ion Concentration and (b) $\mathrm{pH}$ on the $\mathrm{NH}_{3}$ Sensor Reflectance Response.

\section{Response Time and Sensor Stability}

The response time of the optical sensor referred to the time taken for the complexation reaction to go to completion. Based on the response time curve shown in Figure. 4, the optical sensor exhibited a fast response upon reaction with $0.0100 \mathrm{M} \mathrm{NH}_{3}$, whereby it took less than 1 min to achieve maximum reflectance intensity at $615 \mathrm{~nm}$, and the reflectance sensor response was stable for up to $90 \mathrm{~min}$. This implied that the formation of immobilized $\left[\mathrm{Ni}\left(\mathrm{NH}_{3}\right)_{6}\right]^{2+}$ complex was rapid, and the charge-transfer complex was stable for $90 \mathrm{~min}$ before it was dissociated.

Dynamic Linear Range and Limit of Detection of $\mathrm{NH}_{3}$ Optical Sensor

Dynamic linear range, i.e. the calibration curve of the optical sensor is the linear proportionality between the concentration of the analyte $\left(\mathrm{NH}_{3}\right)$ in sample ${ }^{20}$ and reflectance response is presented in Fig.-5. The 
RASĀYAN J. Chem.

Vol. 13 | No. 2 |860 - 867| April - June | 2020

fabricated reflectometric $\mathrm{NH}_{3}$ sensor demonstrated a linear response concentration range from $0.0003 \mathrm{M}$ to $0.0080 \mathrm{M} \mathrm{NH}_{3}$ with a linear regression equation $\mathrm{y}=20.997 \mathrm{x}+1.7728$, and correlation coefficient value, $\mathrm{R}^{2}=0.9826$. The $\mathrm{R}^{2}$ value approaching 1 shows that the data has a perfectly linear relationship between $\mathrm{NH}_{3}$ concentration and reflectance response ${ }^{21}$. The limit of detection (LOD) that was obtained based on the lowest $\mathrm{NH}_{3}$ concentration that can be quantified by the developed silica microspheres-based reflectance $\mathrm{NH}_{3}$ sensor was estimated at $0.0012 \mathrm{M}^{22}$.

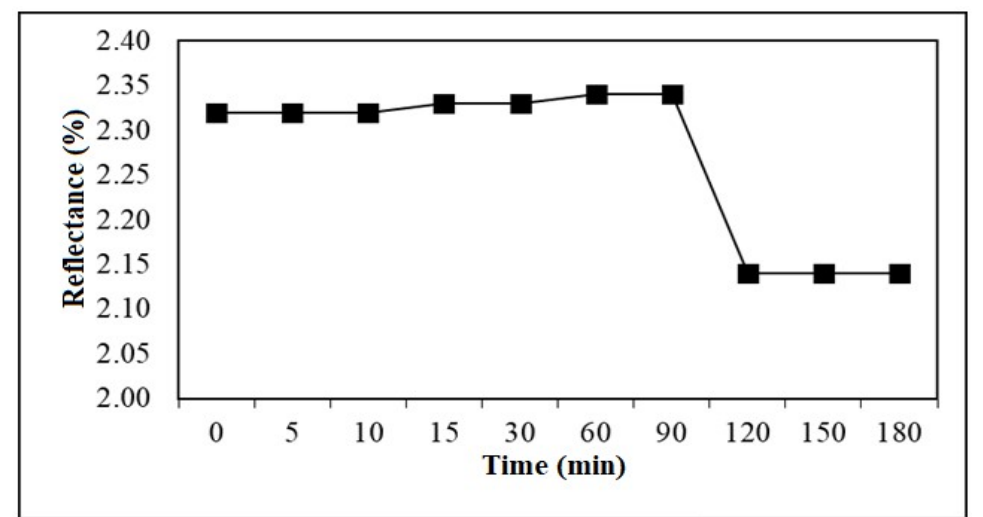

Fig.-4: The Response Time Curve and Stability of the Immobilized $\left[\mathrm{Ni}\left(\mathrm{NH}_{3}\right)_{6}\right]^{2+}$ Complex at $\mathrm{pH} 6$.

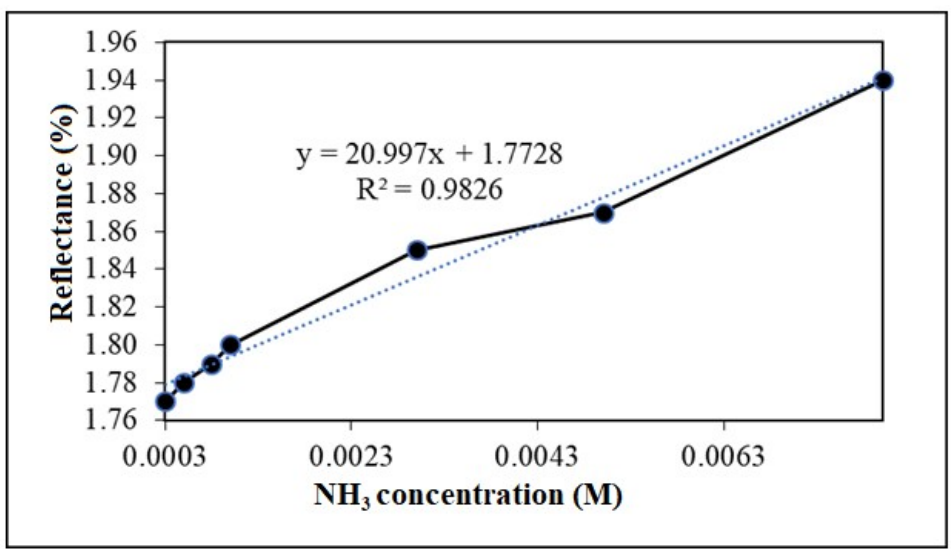

Fig.-5: The Linear Response Curve of the Optical $\mathrm{NH}_{3}$ Sensor between $0.0003 \mathrm{M}$ and 0.0080 M.

\section{Reproducibility and Recovery Performance of Sensor}

Reproducibility is the closeness of the agreement between reflectance responses of 7 similar microsensors, which were batch-produced with the same methodology and the same experimental conditions. Based on the reflectance responses obtained from the optical sensors in the presence of 0.0100 $\mathrm{M} \mathrm{NH}_{3}$ at $615 \mathrm{~nm}$, a reproducibility RSD was calculated at $0.25 \%$. The small RSD value implies that the fabricated optical sensors are identical with the proposed fabrication manner, and negligible variance between optical responses, and that the data points tend to be very close to each other with the same $\mathrm{NH}_{3}$ concentration measurement.

The accuracy of an analytical method is calculated as the recovery percentage of the assay of known spiked target analyte concentration in the real sample. The ideal frame of an acceptable recovery percentage is $80.0-120.0 \%$. In the present study, the percentage recovery of the known added amount of $\mathrm{NH}_{3}$ in the polluted water sample by the proposed silica microspheres-based reflectance sensor was $101.5 \%$, and this percentage recovery is fell within the ideal frame of recovery, and that the developed optical sensor is considered as an acceptable valid method for assessing $\mathrm{NH}_{3}$ in environmental water samples.

Table-1 summarizes the analytical performance of previously reported optical sensors employing various immobilization matrices for comparison with the proposed $\mathrm{Ni}$ (II) ion-doped silica microspheres 
reflectance sensor for $\mathrm{NH}_{3}$ quantification. Based on this comparative analysis, it can be concluded that the proposed reflectometric optical $\mathrm{NH}_{3}$ sensor is comparable to the other previously reported sensors concerning dynamic linear detection range and sensor detection limit.

Table-1: A Comparison of the Analytical Performance of Previously Reported Optical Sensors Employing Various Immobilization Matrices with Present Developed An Optical Sensor for $\mathrm{NH}_{3}$ Detection.

\begin{tabular}{l|c|c|c}
\hline \multicolumn{1}{c|}{ Immobilization Matrix } & Linear Range $(\mathrm{M})$ & Limit of Detection $(\mathrm{M})$ & References \\
\hline Silica microspheres & $3.0 \times 10^{-4}-8.0 \times 10^{-3}$ & $1.2 \times 10^{-3}$ & This work \\
\hline $\mathrm{ZnO}: \mathrm{Eu}^{2+}$ nanoparticles & $3.0 \times 10^{-4}-4.7 \times 10^{-3}$ & $1.2 \times 10^{-3}$ & 23 \\
\hline Plastic clad silica & $5.9 \times 10^{-4}-5.9 \times 10^{-2}$ & $5.9 \times 10^{-4}$ & 25 \\
\hline $\begin{array}{l}\text { Guar gum biopolymer/silver } \\
\text { nanoparticles nanocomposite }\end{array}$ & $5.9 \times 10^{-4}-2.9 \times 10^{-3}$ & $5.9 \times 10^{-4}$ & \\
\hline $\begin{array}{l}\text { Polyaniline/glycidyl ether of } \\
\text { bisphenol composite film }\end{array}$ & $5.4 \times 10^{-3}-2.7 \times 10^{-1}$ & $5.4 \times 10^{-3}$ & 26 \\
\hline
\end{tabular}

\section{CONCLUSION}

An $\mathrm{NH}_{3}$ optical sensor based on silica microparticles doped with $\mathrm{Ni}(\mathrm{II})$ ions has been successfully developed, and carefully optimized with reflectance transduction technique. $\mathrm{Ni}(\mathrm{II})$ ions ware immobilized to silica microparticles through electrostatic interaction and gave green coloration to the silica microspheres surface. Upon reaction with $\mathrm{NH}_{3}$ molecules, the $\mathrm{Ni}(\mathrm{II})$ ion-modified silica microsphere rapidly turned to blue hue due to the formation of the immobilized charge-transfer complex. The $\mathrm{NH}_{3}$ concentration was quantified by measuring the reflectance intensity of the sensor as the color change of the optical sensor from green to blue was proportional to the increasing $\mathrm{NH}_{3}$ concentration. The proposed optical $\mathrm{NH}_{3}$ sensor possessed good reproducibility and recovery performance with linear response range and limit of detection that are comparable to some other optical $\mathrm{NH}_{3}$ sensors reported in the literature.

\section{ACKNOWLEDGMENT}

We would like to thank the Indonesian Ministry of Technology Research and Higher Education for a topdown research grant with research fund number 191/SP2H/LT/DRPM/2019.

\section{REFERENCES}

1. Y. Huang and S. Tao, Journal of Sensor Technology, 01(02), 29(2011), DOI:10.4236/jst.2011.12005

2. M. Ismail, M.I. Khan, K. Akhtar, M.A. Khan, A.M. Asiri and S.B, Khan, Physica E: Lowdimensional Systems and Nanostructures, 103, 367(2018), DOI:10.1016/j.physe.2018.06.015

3. S. Dai, N. Prempeh, D. Liu, Y. Fan, M. Gu and Y. Chang, Carbohydrate Polymers, 174), 531(2017), DOI:10.1016/j.carbpol.2017.06.098

4. S. Narasimman, L. Balakrishnan and Z.C. Alex, IEEE Sensors Journal, 18(1), 201(2018), DOI:10.1109/JSEN.2017.2769718

5. K. Waich, T. Mayr and I. Klimant, Talanta, 77(1), 66(2008), DOI:10.1016/j.talanta.2008.05.058

6. S. Porrello, G. Ferrari, M. Lenzi and E. Persia, Aquaculture, 219(1-4), 485(2003), DOI:10.1016/S0044-8486(02)00637-3

7. https://www.ncbi.nlm.nih.gov/pmc/articles/PMC3385445/

8. R.B. Soni and R. Dhankhar, Rasayan Journal Chemistry, 8(4), 452(2015)

9. A.R. Rahmani, A.H. Mahvi, A.R. Mesdaghinia and S. Nasseri, International Journal of Environmental Science \& Technology, 1(2), 125(2004), DOI:10.1007/bf03325825

10. J.X. Dong, Z.F. Gao, Y. Zhang, B.L. Li, N.B. Li and H.Q. Luo, Biosensors and Bioelectronic. 91, 155(2017), DOI:10.1016/j.bios.2016.11.062

11. S. Ruan, J. Lu, N. Pai, H. Ebendorff-Heidepriem, Y.B. Cheng, Y. Ruan and C.R. McNeill, Journal of Materials Chemistry C, 6(26), 6988(2018), DOI:10.1039/C8TC01552J

12. H.Yang and Y. Zhu, Talanta, 68(3), 569(2006), DOI:10.1016/j.talanta.2005.04.057

13. A. Ulianas, L.Y. Heng and M. Ahmad, Sensors, 11(9), 8323(2011), DOI:10.3390/s110908323

14. M. Nikolic, K. Giannakopoulos and V. Srdic, Ceramics International, 41(10), 13480(2015), DOI: 866 
RASĀYAN J. Chem.

Vol. 13 | No. 2 |860 - 867| April - June | 2020

10.1016/j.ceramint.2015.07.139

15. U. Zulfiqar, T. Subhani and S.W. Husain Journal of Asian Ceramic Societies, 4(1), 91(2016), DOI: $10.1016 /$ j.jascer.2015.12.001

16. K.S. Rao, K. El-Hami, T. Kodaki, K. Matsushige and K. Makino, Journal of Colloid and Interface Science, 289(1), 125(2005), DOI:10.1016/j.jcis.2005.02.019

17. T.D. George and W.W. Wendlandt, Journal of Inorganic and Nuclear Chemistry, 25(4), 395(1963), DOI: 10.1016/0022-1902(63)80190-6

18. A. Basker, P.S. Syed Shabudeen, S. Daniel and P. Vignesh Kumar, Rasayan Journal Chemistry, 7(1), $1(2014)$

19. M. Reháková, A. Sopková, P. Králik and T. Falt’anová, Thermochimica Acta , 74(1-3), 1(1984), DOI: 10.1016/0040-6031(84)80001-5

20. S.K. Mastanamma, K. Sravani and T. Anil, Rasayan Journal Chemistry, 8(3), 303(2015)

21. N. Altman and M. Krzywinski, Nature Methods, 12(11), 999(2015), DOI:10.1038/nmeth.3627

22. B. Timmer, W. Olthuis and A. Van Den Berg, Sensors and Actuators B: Chemistry, 107(2), 666(2005), DOI:10.1016/j.snb.2004.11.054

23. W. Yang, W. Feng, X. Yang, H. Chen, Y. He, D. Deng and Peng, Zeitschrift Für Naturforschung, 0(0), 1(2018), DOI:10.1515/zna-2018-0244

24. W. Cao and Y. Duan, Sensors and Actuators B: Chemistry, 110(2), 252(2005), DOI: $10.1016 /$ j.snb.2005.02.015

25. S. Pandey, G.K. Goswami and K.K. Nanda, International Journal of Biological Macromolecules, 51(4), 583(2012), DOI:10.1016/j.ijbiomac.2012.06.033

26. A. Airoudj, D. Debarnot, B. Bêche and F. Poncin-Epaillard, Talanta, 77(5), 1590(2009), DOI: 10.1016/j.talanta.2008.09.054

[RJC-5424/2019] 